\title{
IMPROVING BUSINESS HELPDESK SYSTEMS WITH INTELLIGENT SEARCH MECHANISMS
}

\author{
Vladimir Milicevic ${ }^{1}$ \\ Technical College of Applied Studies in Kragujevac, Kragujevac Serbia \\ Slavoljub Milovanovic \\ Faculty of Economics in Nis, Niš Serbia \\ Bojana Milosavljevic \\ VTSSS Zvecan, Serbia
}

\begin{abstract}
Modern information systems widely use intelligent tools for detection, recognition and prediction of new knowledge. The area of implementation of such systems is huge and there is almost no area of industry and services, where such systems are not represented. The aim of the development of such systems is to obtain such an information system in the future that will have full functionality with the ability to upgrade without the intervention of a software development team.

The paper proposes an intelligent software solution as a part of the way toward the set ideal software solution. It will particularly highlight that the methodology by which the prototype of the proposed software solution was developed represents a valid basis for the development of software solutions for different areas and services.
\end{abstract}

Keywords: insurance, rule, knowledge base, intelligent system, HelpDesk, neural networks.

Сажетак: Савремени пословни информациони системи увелико користе интелигентне алате за откривање, препознавање и предвиђање новог знања. Област примене оваквих система је огромна и скоро да не постоји област индустрије и услуга у којој примена оваквих система није заступљена. Циљ развоја оваквих система јесте обезбеђивање потпуно функиионалне класе информационих система која ће имати могућност надоградње без потребе за интервениијом од стране развојног софтверског тима.

Рад предлаже интелигентно софтверско решење као међу-фазу у развоју идеалног софтверског решења способног за самостално одржавање. Посебно ће бити истакнуто да методологија, по којој је прототип пословног софтверског решења развијен, представља валидну основу за развој софтверских решења за бројна подручја индустрије и услуга.

Ključne reči: осигурање, правило, база знања, интелигентни систем, HelpDesk, неуронске мреже.

\section{INTRODUCTION}

In today's business environment, every business entity is necessarily directed toward the use of ICT. The quality of modern software solutions for supporting business is directly related to the

${ }^{1}$ vladam.kg@outlook.com

Vol. 17, бpoj 2/2015, cmp. 123-137 
efficiency and effectiveness of business activity and achieving strategic advantage over the competition. Due to the increasing power of search, recognition and prediction of the state of the products and services markets the development of information systems is focused on advanced intelligent techniques and tools, such as neural networks, genetic algorithms, fuzzy logic, etc. Application area of these systems is enormous, starting from the recognition of consumer behavior in large hypermarket chains, through the use in the insurance industry for prediction of movements in the stock exchange and markets, to robotics (Medina-Santiago A, Camas-Anzueto J. L, Vascuez-Feijoo J. A, Hernández-de León H. R, Mota-Grajales R, 2014), the system of smart sensors (Rivera-Mejía J, Léon-Rubio A. G, Arzabala-Contreras E, 2012), mobile devices (Nalepa, G. J., Bobek, S, 2014), advanced systems of advertising (Rodríguez-González, A., Torres-Niño, J., Jimenez-Domingo, E., Gomez-Berbis, J. M., Alor-Hernandez, G, 2012) etc.

The ability to customize software solutions to support business dynamic changes of the modern business environment is of particular importance. Authors S. Codington and T.D. Wilson argue that information technologies (IT) and information systems have a central role in the insurance business and insurance companies recognize that they need to keep the business running and are aiming to use IT to develop new markets and to maintain competitiveness (Codington S, Wilson T.D, 1994).

It is also necessary to mention the various forms of usage of modern software solutions in the insurance industry for supporting next tasks (my.safaribooksonline.com/book/management, seen 03.02.2015.):

1. Manage customer relationship

2. Manage sales force effectively

3. Help customer to instantly access information, and provide solutions instantly

4. Remind customers of service requirements, and provide periodic follow-up and alerts

5. Outline enquiry and transactions providing customer satisfaction

6. Automatic reporting and metrics to monitor performance and productivity.

The given hypothesis should expand the possibilities of electronic communication within the company. Development of appropriate HelpDesk system, where employees would receive advice from experts at different levels, could greatly improve the business of an insurance company. Obtaining accurate and timely information would bring employee satisfaction to a higher level and thus would increase the effectiveness and efficiency of their work. However, the response rate to 
the question asked depends on when the expert who has been asked the question will respond to it. Hence, there is a need for reflection and research on the development of software solutions that will transfer the expertise from the man to the computer to the greatest extent possible.

\section{CURRENT SITUATION}

The success of the insurance companies business is largely based on the maximum lowering of operating costs. Hence, the justification for investing in the software supplied with HelpDesk support must be sought in the field of reducing total operating costs. Since this is a very profitable field of products and services, the greatest participants in the market of software development greatly offer their own solutions for support to the insurance industry.

One of the best solutions on the market is a product of Dell. The software solution has been implemented for servicing business of Hiscox (UK) insurance company. Since the introduction of this system, to this day, Hiscox has made huge benefits. Insurance company saves $75 \%$ of a service desk FTE within nine months of launch. Also, Hiscox improves security and prepares for business growth with automated identity and access management software from Dell (www.quest.com, seen 03.02.2015).

Also, the very solution is a product of LBi Software LBi known as HR HelpDesk. In developing HR HelpDesk LBi, LBi listened and responded to the wants and needs of a customer and then implemented an ideal solution that perfectly meshed with that client, a major North American life insurance company. By reducing overall problem resolution times and increasing the number of successful calls, LBi HR HelpDesk improved the performance of CSRs while increasing employee satisfaction and retention (www.lbisoftware.com, seen 03.02.2015). The ability of the above given solution to provide managers with management based on the growing knowledge base consisting of standard problems and their solutions is of particular importance to this paper.

Area of research that this paper relies on is the ability to recognize a false statement in compensation claims of insurance beneficiaries and serving timely accurate information to the employee of the company that processes the request for compensation through HelpDesk system. What is extremely important in this field is the solution from IBM that offers tools to the insurance companies for detection and elimination of compensation claims in the event of making false statements. IBM claims fraud solution takes a comprehensive approach that addresses fraud at

Vol. 17, бpoj 2/2015, cmp. 123-137 
every stage of the claim lifecycle both on a right time and inline basis (figure 1) (www-01.ibm.com, pristup 03.02.2015).

In the past systems for prevention and fighting against these types of statements were not adequately addressed. The insurance companies had great losses compensating the damage that was documented by false statements. Developed and rich countries spend enormous resources to prevent and combat this phenomenon. In 2010, the U.S. Congress proposed a budget of U.S. $\$ 1.7$ billion to fight healthcare fraud (Torpey D, 2011).

Figure 1.: Logic of IBM claims fraud solution

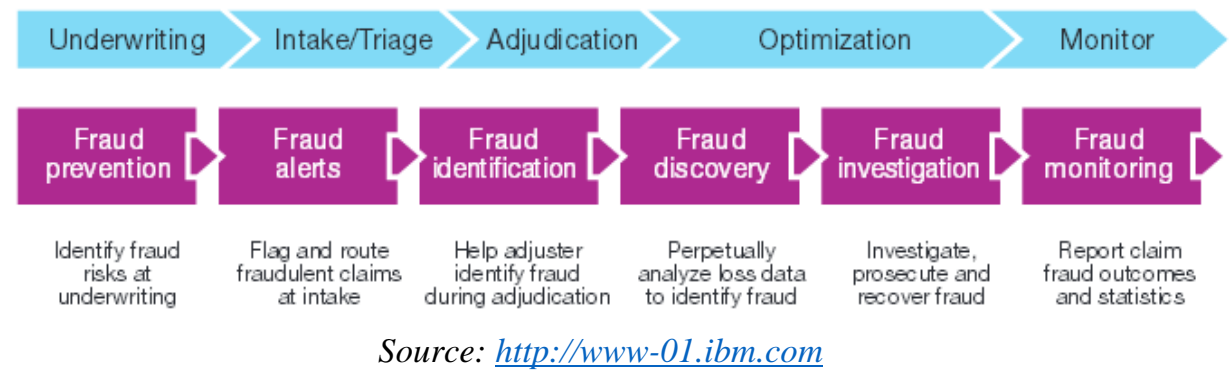

In the light of these facts, the development of advanced computer systems that will be able to completely eliminate the occurrence of false statements in client requests for compensation will be a priority for leading companies in the field of insurance. There are numerous approaches to the search for possible solutions. This paper proposes a hybrid approach to developing a computer system that uses intelligent components for search, e.g. neural networks combined with software development that enables dynamic management of knowledge bases. For employees of the insurance company, this system will through HelpDesk immediately answer the question: 'Is the client's request for compensation suspicious or not'.

Also, such a system must have the ability to learn and dynamically adapt to new and emerging circumstances related to the business of the company it services.

\section{CASE STUDY - HYBRID COMPUTER SYSTEM FOR SUPPORTING THE MERIDIAN PROJECT INSURANCE COMPANY BUSINESS}

In the light of the foregoing exposure it is necessary to identify the following requirements for the development of a software solution: 
1. Provide a way to dynamically integrate the rules, new knowledge into the information system knowledge base through HelpDesk support;

2. Provide intelligent mechanisms for searching, predicting and recognizing false statements from a relevant sample;

3. Provide automatic coding of newly discovered knowledge and its implementation with tools stated under 1 ;

4. Develop a prototype system, with an innovative approach, based on the given requirements;

5. Identify an adequate hardware support for efficient and effective functioning of the system.

The field in which solutions should be looked for is objectoriented software development, combined with techniques and tools for the development of intelligent systems. Object-oriented techniques and tools, forced by JAVA Enterprise Edition, are responsible for development of next software components: core of application or server, neural network searching algorithm and client application, both desktop and mobile. Database, built on MySQL server, is managed by server using object - relational tool Hibernate ORM. Knowledge base is organized in object-oriented way, rule patterns are classes and concrete rules are object of these classes. Approach that allows such knowledge base organization is known as aspect - oriented programming. Aspect oriented notation AspectJ+ is applied for rule classes and related objects construction in concrete software solution.

Authors H. Daniels and H. van Dissel proposed an approach in their work which suggests monotone neural network combined with the determination of risk index over the set $(0.1)$ for searching the sample. The authors believe that the reference value of the risk index is 0.5 . The lower value of the value of the reference points to the correct statement while the higher stresses that statement is suspicious (Daniels $\mathrm{H}$, van Dissel H, 2002).

This paper proposes the improvement of the above given approach using neural network pattern which searches texts, statements database, using appropriate search algorithm in conjunction with the method of reserved words and Zipf's law. Text search with intelligent tools has recently become the subject of research of many authors (Bechet, N., Chauche, J., Prince, V., Roche, M, 2014.). The paper suggests the backpropagation algorithm to be the optimal search algorithm. In contemporary literature there is a very large number of ways of applying this algorithm. Human brain consists of $10^{11}$ sets of interconnected neurons to facilitate our reading, breathing, motion and thinking. In term of learning, human brain is superior to a microprocessor. Because of that 
fact, backpropagation network tries to adapt the ability of human brain to learn by experience (Yeremia H, Adrianus Yuwono N. A, Raymond P, Budiharto W, 2013). Zipf's law refers to the frequency of words in the sample, and reserved words are certain guidelines to create rules in the knowledge base. The aim of this paper is a knowledge base that on the basis of this search mode is constantly growing and expanding with new patterns. Rules-based systems test each transaction against a predefined set of algorithms or business rules to detect known types of fraud based on specific patterns of activity (SAS, 2012).

Through searching process, the software solution filters the user's statement and puts it on the coding in the form of a business rule. If the rule pattern already exists in the knowledge base, the employee of the insurance company, in charge of the case, immediately receives a response with regard to the question about the case, through the HelpDesk. If the system recognizes the new knowledge, the fraud detection expert gets the rule pattern for inspection through HelpDesk. If the rule is approved, the expert forwards it by one click to the knowledge base automatically, without the need for recompilation and the intervention of a software development team. Cycle time statements sample to solve cases that are related to a set of statements can be shown in Figure 2. Optimal notation for control and encoding of new knowledge can be found in the paper the author of which is M. A. Cibran (Cibran M. A, 2007). By combining high-level language and aspect-oriented tools, customized for a particular problem, it is possible to dynamically integrate new knowledge. On the basis of a set of reserved words (Table 1) a new rule is created which will automatically be forwarded to the knowledge base after being approved by an expert.

Based on the methodology given in the paper (Stankic $R$, Milićević V, Popović M, Savić Z, 2012), and in the light of the requests a new information system prototype with the HelpDesk support has been created at the requirement of Meridian Project Group. Methodology suggests software development that follows next steps:

1. Two-way model driven engineering approach must be applied in object - oriented analysis and design;

2. Rule patterns must be defined at high level - domain level;

3. Rule definition must be object - oriented, not in if - then - else structured way;

4. Knowledge base must be filled with rule classes and objects which have loose connections with server through specialized connecting objects known as aspects;

5. Scenarios of rules implementation must me defined, also, at domain level; 
6. Mentioned knowledge base organization allows new knowledge integration without re-compiling of the software solution;

7. Knowledge discovering and using scenarios must be defined and implemented in backpropagation algorithm for neural network training.

Numerous tests related to the following have been done:

1. Choosing an ideal topology and algorithm for neural network training.

2. Measuring the speed of resolving the case relying on HelpDesk without intelligent support for the search- all requests are sent to experts for approval.

3. Measuring the speed of resolving the case by using the complete functionality of the observed software solution.

Table 1.: Reserved words set

\begin{tabular}{|l|}
\multicolumn{2}{|c|}{ Reserved words set } \\
\hline BR \\
IF \\
THEN \\
AND \\
OR \\
NOT \\
PROPS \\
AS \\
USING \\
WHERE \\
CONNECT \\
BEFORE \\
AFTER \\
INSTEAD \\
OF \\
\hline
\end{tabular}


Figure 2.: Searching the sample and approving the request

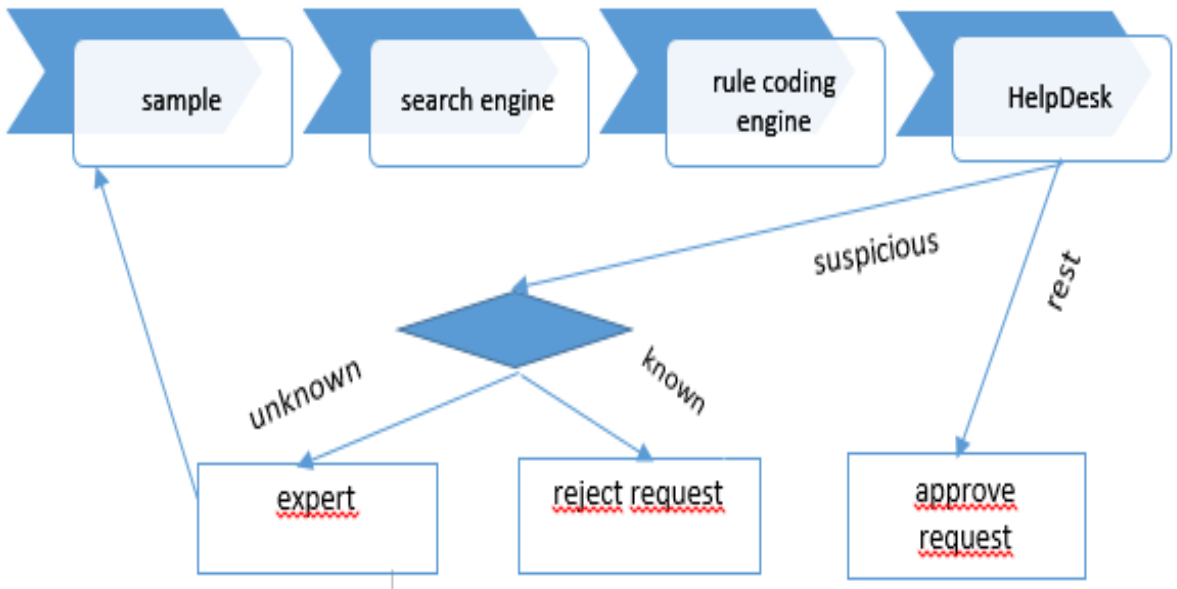

According to the above given methodology (Stankić R, Milićević V, Popović M, Savić Z, 2012), the ideal algorithm is backpropagation algorithm in combination with the architecture of the network of 10 neurons in the hidden layer. This proves how universal this methodology is in the broader field of the development of intelligent software solutions.

\subsection{SYSTEM REACTION SPEED WITHOUT THE INTELLIGENT SUPPORT}

Within one hour the employees forwarded 1000 different questions related to compensation claims through HelpDesk system to the experts for consideration. The results are shown in Table 2 and Chart 1.

Table 2.: Resolution time for requests by the system without intelligent search.

\begin{tabular}{|c|c|c|c|c|c|}
\hline & 1. hour & 3. hour & 5. hour & next day & $\begin{array}{l}\text { longer } \\
\text { period }\end{array}$ \\
\hline solved & 428 & 230 & 142 & 98 & 102 \\
\hline$\%$ & 42,8 & 23 & 14,2 & 9,8 & 10,2 \\
\hline
\end{tabular}


The given data give us the possibility to see the dominance of the human factor in solving the problem and in the decision making. The speed of the expert's response in some cases is not at the appropriate level.

\section{Chart 1.: Request resolution time by the system without intelligent} search.

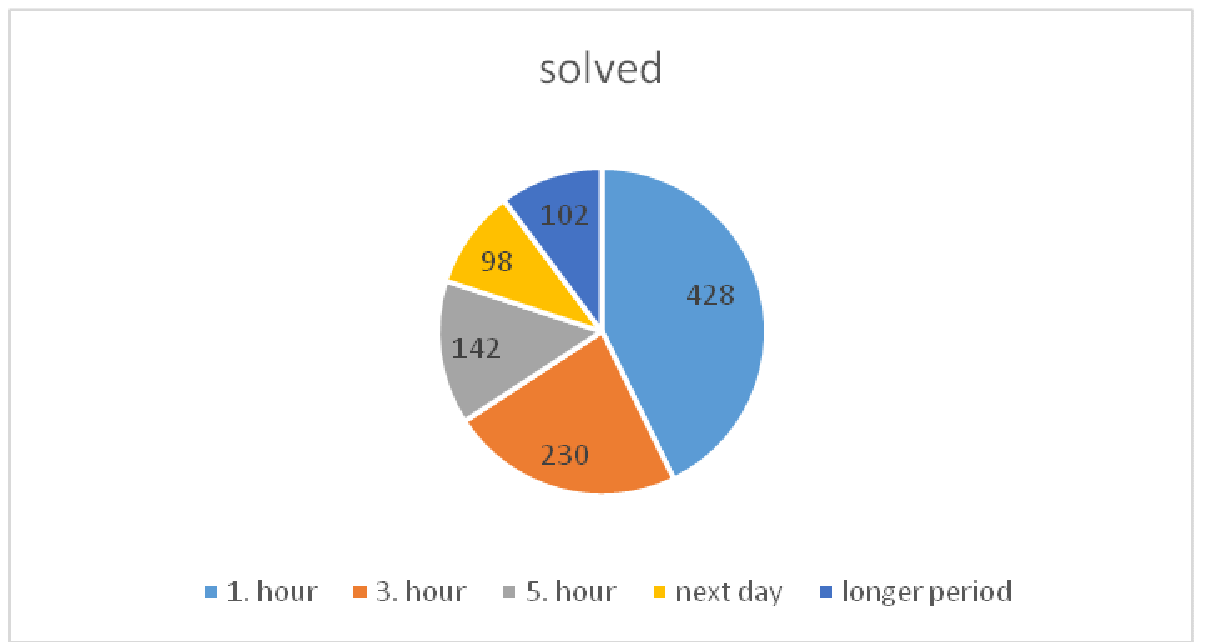

\subsection{SYSTEM REACTION SPEED WITH THE USE OF THE INTELLIGENT SUPPORT}

The identical sample is forwarded by an extended software solution through HelpDesk. Patterns for 998 questions already exist in the knowledge base. There is no such pattern in the knowledge base that could identify the following statement: 'On June 82014 around 1 a.m. I was going back home after the night out in the city. At a certain crossroads a red car went through the red light and hit my car in the rear door. The driver who caused the accident left the scene and my cell phone was turned off because the battery had died out so I couldn't call the police. My car was in such a state that I could drive it so I went home. I would like to ask you to compensate this damage based on the policy number PNo 0003062014 - Petar Petrovic, personal identification number 0706993xxxxxx".

The expert can clearly see from the given statement that this 21year -old male (based on personal identification number) was out on his birthday. Also it's clear that it was a weekend and according to the experience of the insurance company weekend is the time when alcohol is most consumed. The person left the scene of the accident without a police record which is the most valid document for a compensation claim. 
Having processed the sample the expert has received a statement in the form of new knowledge which is now supposed to be classified as valid or suspicious. The software has generated the following code that corresponds to the new rule:

BR BRHollidayAccident

PROPS Integer As age, DateTime As date, DateTime As hour, Boolean As PoliceReport, Boolean As LeftPlace

USING Policy.Base As policy

WHERE User Is policy.number

IF date Is [Fri|Sat|Sun] And (hour $>=\# 22: 00 \#$ And hour $<=\# 7: 00 \#)$ And

PoliceReport $=$ False And Left $=$ True

THEN policy.SendToSuspicious()

A click on the 'Suspicious' button turns the rule into the appropriate implementation code and is immediately sent to the knowledge base (Figure3). The employee that has sent the request to the expert instantly gets an approval to reject the compensation claim.

The knowledge base also does not have a pattern that would fit the following statement: 'On June 62014 I fell down the stairs at my workplace. I was taken to the doctor immediately and the doctor stated that I had sprained my ankle (injury). I was given the appropriate treatment and further therapy and the doctor's report as a document for the compensation claim. I also got absence (rest) from work for a period of 20 days. I would like to ask you to compensate this injury based on the policy number PNo 0003062028- Nikola Nikolić, personal identification number $1106973 \mathrm{xxxxxx"}$ ".

Based on the forwarded statement the expert has information that indicate that the person who owns the policy that covers work injury went timely to the doctor and got all the necessary proof for the approval of the compensation claim. Based on the search, the software generated the following rule:

BR BRAccidentAtWork

PROPS Integer As age, DateTime As date, DateTime As hour, Boolean As DoctorReport, Boolean As Injury, Boolean As Rest, Boolean As Therapy

USING Policy.Base As policy

WHERE User Is policy.number

IF DoctorReport $=$ True And Injury $=$ True And Rest $=$ True And Therapy

$=$ True

THEN policy.SendToAccepted() 
A click on the 'Approved' button turns the rule into an executable code and forwards it to the knowledge base (Figure 4.). The employee that has asked the question through HelpDesk system is told to approve the compensation claim.

Table 3. and Chart 2. Show the speed at which the forwarded claims were processed.

Table 3.: Request resolution time by the system with intelligent search

\begin{tabular}{rrr} 
& $<5 \min$ & After 5 min \\
\hline solved & 998 & 2 \\
$\%$ & 99,8 & 2
\end{tabular}

Chart 2.: Request resolution time by the system with intelligent search

Solved




\section{Figure 3.: 'Suspicious' rule executable code from knowledge base}

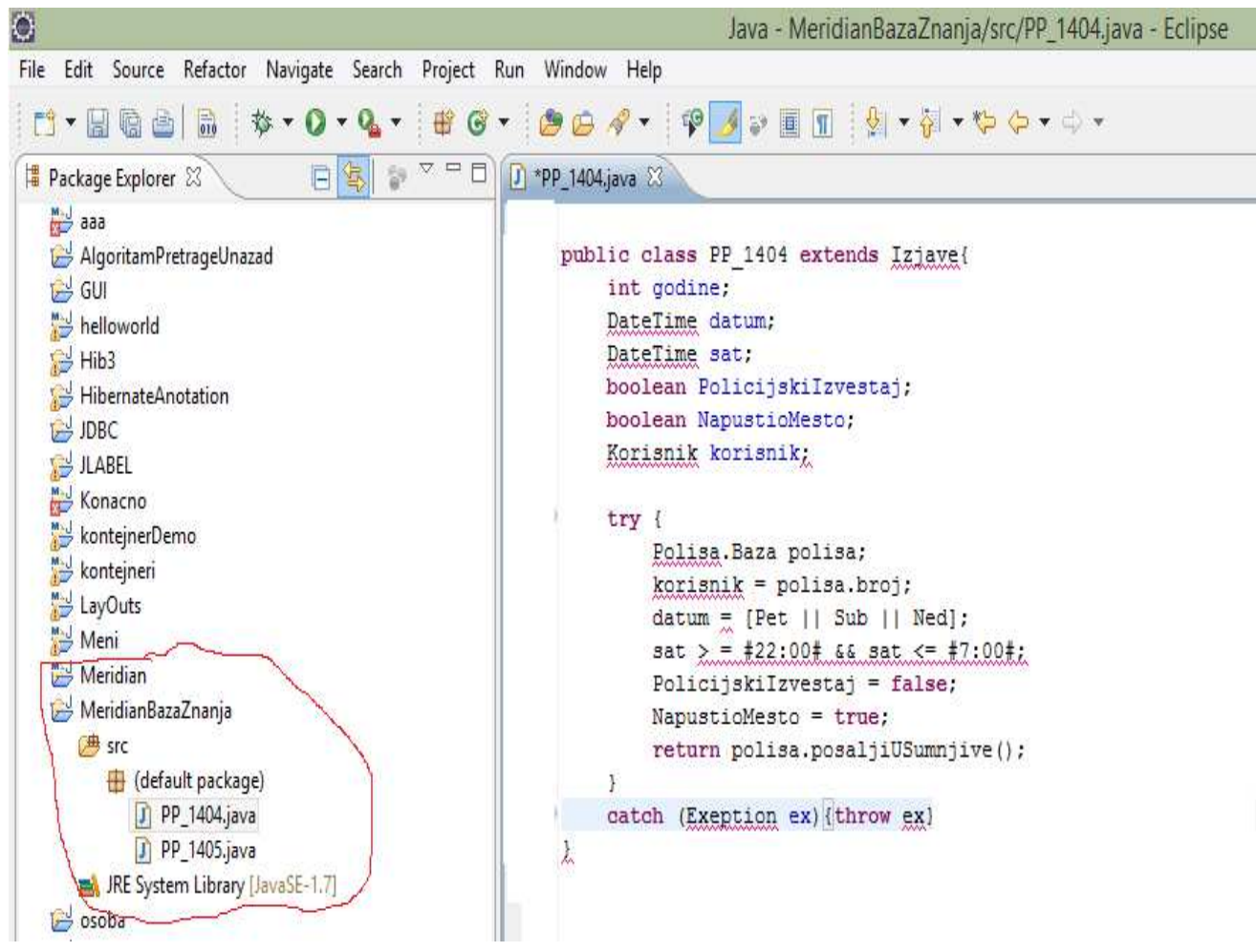

Figure 4.: 'Approved' rule executable code from knowledge base

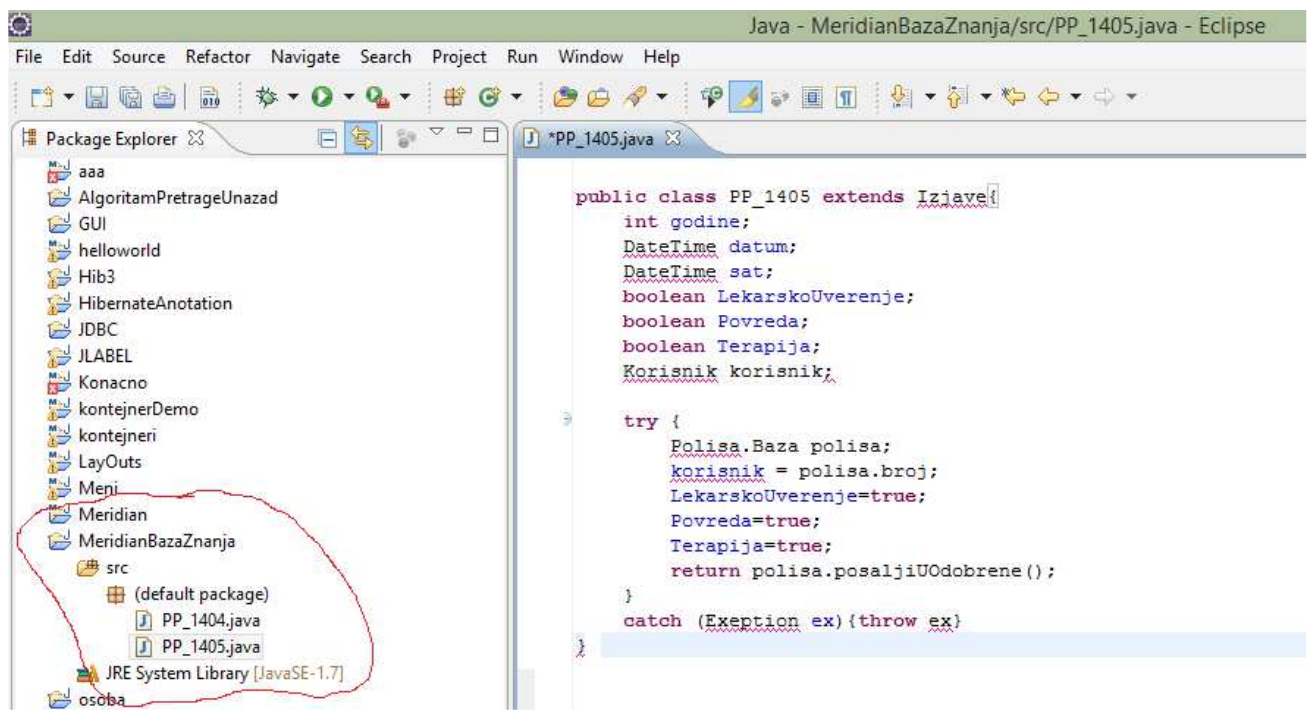


Figure 5.: Intelligent HelpDesk implementation - web client

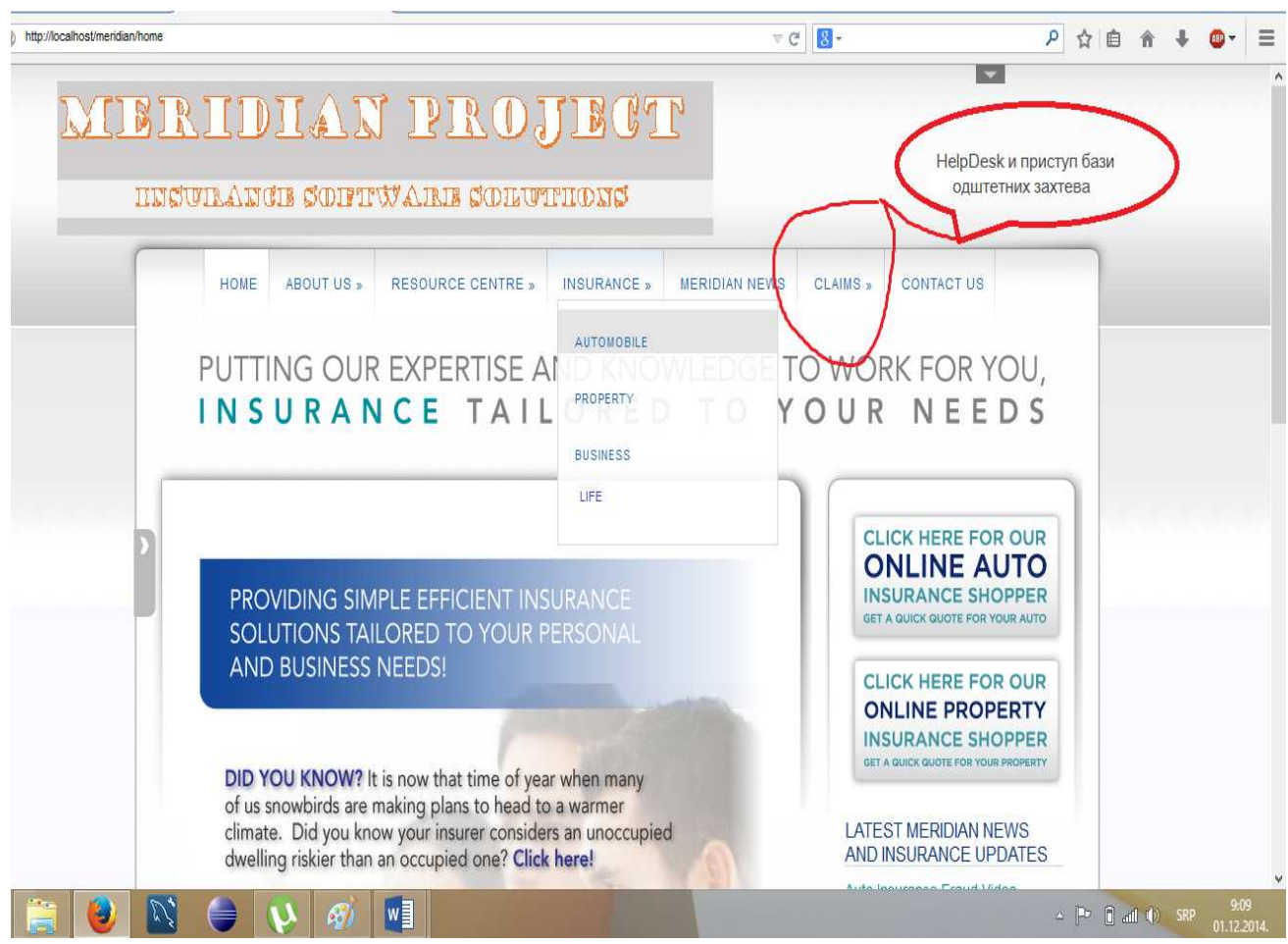

\section{CONCLUSION}

Based on the tests that were done it is possible to conclude that the application of intelligent techniques of software development can result in great benefits for companies that use such software in their own business. The benefits are the following:

- Increased efficiency and effectiveness of operations

- Lower operating costs - the company needs less people to do the greater amount of work

- The marketing side of the introduction of such a system is reflected in the improved company image.

- Increased employee satisfaction through getting timely, precise information via HelpDesk system.

- Increased satisfaction of insurance company beneficiaries due to shorter period of time needed for resolution of their compensation claims, etc.

In addition to these considerations it is also possible to conclude that the insurance company investments in information systems, built on 
these object-oriented techniques with extensions for supporting the development of intelligent software components will soon be justified. The increase in business volume and higher profit will be the result of that.

The insurance industry is just one area in which intelligent computer systems are experiencing expansion. To make this system completely independent of human (expert) intervention, it may take more time. It is able to learn with the support and intervention of experts. For the system to be able to learn on its own it is necessary to provide a knowledge base with all possible scenarios for comparing newly discovered knowledge. In such case the expert would be needed to approve the new rule which is a limitation of this support.

\section{REFERENCES}

1. Bechet, N., Chauche, J., Prince, V., Roche, M. (2014). How to Combine Text-Mining Methods to Validate Induced Verb-Object Relations. Computer Science and Information Systems, Vol. 11, No. 1, 133-156. (2014)

2. Codington, S. \& Wilson, T.D. (1994). Information System Strategies in the U.K. Insurance Industry International Journal of Information Management, 14(3), 188-203

3. Cibran M. A. (2007). Connecting High-Level Business Ruleswith Object-Oriented Applications:An approach using AspectOrientedProgramming and Model-DrivenEngineering, Uitgever VUBPRESS

4. Daniels H, van Dissel H. (2002). Risk management based on expert rulesAnd data-mining: a case study in insurance, ECIS 2002 - June 6-8, Gdańsk, Poland

5. Medina-Santiago A, Camas-Anzueto J. L, Vascuez-Feijoo J. A, Hernández-de León H. R, Mota-Grajales R. (2014). Neural Control System in Obstacle Avoidance in Mobile Robots UsingUltrasonic Sensors, Journal of Applied Research and Technology, vol. 12 (2014), 104-110.

6. Nalepa, G. J., Bobek, S. (2014). Rule-Based Solution for ContextAware Reasoning on Mobile Devices, Computer Science and Information Systems, Vol. 11, No. 1, 171-193. (2014)

7. Rivera-Mejía J, Léon-Rubio A. G, Arzabala-Contreras E. (2012). PID Based on a Single Artificial Neural Network Algorithm for Intelligent Sensors, Journal of Applied Research and Technology, vol. 10 No.2 (2012), 262-282. 
8. Rodríguez-González, A., Torres-Niño, J., Jimenez-Domingo, E., Gomez-Berbis, J. M., Alor-Hernandez, G. (2012). AKNOBAS: A Knowledge-based Segmentation Recommender System based on Intelligent Data Mining Techniques. Computer Science and Information Systems, Vol. 9, No. 2, 713-740. (2012)

9. SAS. (2012). Combating Insurance Claims Fraud - How to Recognize and Reduce Opportunistic and Organized Claims Fraud, SAS White Paper

10. Stankić R, Milićević V, Popović M, Savić Z. (2012). Contribution to Intelligent System for Automatic Management of Business Rules Development, (TTEM Vol. 7/1 - 2012).

11. Torpey D. (2011). Fraud in insurance on rise - survey 2010-2011, Ernst \& Young 2011

12. Yeremia H, Adrianus Yuwono N. A, Raymond P, Budiharto W. (2013). Genetic Algorithm And NeuralNetwork For Optical Character Recognition, Journal of Computer Science 9 (11): 1435-1442, 2013

13. http://www-01.ibm.com/common/ssi/cgibin/ssialias? subtype=SP\&infotype=PM\&appname=SWGE_IM_I M_USEN\&htmlfid=IMS14396USEN\&attachment=IMS14396US EN.PDF

14. http://www.lbisoftware.com/casestudies/LBi-HR\%20HelpDeskCase\%20Study.pdf

15. http://www.my.safaribooksonline.com/book/management/978813 1759844/case-study-on-reliance-life-insurance-use-ofinformation-system-as-a-strategic/c08-sec1-011

16. http://www.quest.com/documents/insurance-company-saves-75percent-of-a-service-desk-fte-within-nine-months-of-launchcasestudy-26716.pdf

Рад је примљен: 27.08.2015. Рад је прихваћен за итампу: 15.09.2015. 